\title{
Irreversible Insertion of Benzonitrile into Platinum(II)-Nitrogen Bonds of Nucleobase Complexes. Synthesis and Structural Characterization of Stable Azametallacycle Compounds
}

\author{
Diego Montagner, ${ }^{\dagger}$ Alfonso Venzo, ${ }^{\ddagger}$ Ennio Zangrando, ${ }^{\S}$ and Bruno Longato*, ${ }^{*}$ \\ ${ }^{\dagger}$ Dipartimento di Scienze Chimiche, Università di Padova, Via Marzolo 1,35131 Padova, Italy, ${ }^{\star}$ CNR, Istituto di \\ Scienze e Tecnologie Molecolari, Via Marzolo 1,35131 Padova, Italy, and ${ }^{\S}$ Dipartimento di Scienze Chimiche, \\ Università di Trieste, Via Giorgieri 1, 34127 Trieste, Italy
}

Received July 29, 2009

\begin{abstract}
Deprotonation of 1-methylcytosine (1-MeCy) and 9-methyladenine (9-MeAd) promoted by cis-[ $\left.\mathrm{L}_{2} \mathrm{Pt}(\mu-\mathrm{OH})\right]_{2}\left(\mathrm{NO}_{3}\right)_{2}(\mathrm{~L}=$ $\mathrm{PPh}_{3}, \mathrm{PMePh}_{2}, 1 / 2 \mathrm{dppe}$ ) in $\mathrm{PhCN}$ causes the irreversible insertion of a nitrile molecule into the $\mathrm{Pt}-\mathrm{N} 4$ and $\mathrm{Pt}-\mathrm{N} 6$ bonds of the cytosinate and adeninate ligands, respectively, to form the stable azametallacycle complexes cis- $\mathrm{L}_{2} \mathrm{PtNH}=$ $\mathrm{C}(\mathrm{Ph})\{1-\mathrm{MeCy}(-2 \mathrm{H})\}] \mathrm{NO}_{3}\left(\mathrm{~L}=\mathrm{PPh}_{3}, 1 ; \mathrm{PMePh}_{2}, 2 ;{ }^{1} / 2 \mathrm{dppe}, 3\right)$ and cis- $\left[\mathrm{L}_{2} \mathrm{PtNH}=\mathrm{C}(\mathrm{Ph})\{9-\mathrm{MeAd}(-2 \mathrm{H})\}\right] \mathrm{NO}_{3}(\mathrm{~L}=$ $\left.\mathrm{PPh}_{3}, 4 ; \mathrm{PMePh}_{2}, 5\right)$ containing the deprotonated form of the molecules (Z)-9-N-(1-methyl-2-oxo-2,3-dihydropyrimidin$4(1 H)$-ylidene)benzimidamide and (Z)- $N$-(9-methyl-1H-purin-6(9H)-ylidene)benzimidamide. Single-crystal X-ray analyses of 2 and 4 show the metal coordinated to the $\mathrm{N} 3$ cytosine site $[\mathrm{Pt}-\mathrm{N} 3=2.112(7) \AA]$ and to the N1 site of adenine $[\mathrm{Pt}-\mathrm{N} 1=2.116(6) \AA]$ and to the nitrogen atom of the inserted benzonitrile $[\mathrm{Pt}-\mathrm{N} 2=2.043(6)$ and $2.010(6) \AA$ in 2 and 4 , respectively], with the exocyclic nucleobase amino nitrogen bound to the carbon atom of the $\mathrm{CN}$ group. Complex 2 , in solution, undergoes a dynamic process related to a partially restricted rotation around $\mathrm{Pt}-\mathrm{P}$ bonds, arising from a steric interaction of the oxygen atom of the cytosine with one ring of the phosphine ligands. The reaction of 4 with acetylacetone (Hacac) causes the quantitative protonation of the anionic ligand, affording the acetylacetonate complex cis- $\left[\left(\mathrm{PPh}_{3}\right)_{2} \mathrm{Pt}-\right.$ (acac) $] \mathrm{NO}_{3}$ and the free benzimidamide $\mathrm{NH}=\mathrm{C}(\mathrm{Ph})\{9-\mathrm{MeAd}(-\mathrm{H})\}$. In the same experimental conditions, complex 3 reacts with Hacac only partially.
\end{abstract}

\section{Introduction}

The coordination of a nitrile $(\mathrm{RC} \equiv \mathrm{N})$ to a metal center $[\mathrm{M}]$ increases the rate of the nucleophilic attack to the carbon atom of the $\mathrm{CN}$ group. ${ }^{1}$ When the nucleophile $(\mathrm{Nu})$ is a protic species, the imino derivative $[\mathrm{M}]-\mathrm{NH}=\mathrm{C}(\mathrm{Nu}) \mathrm{R}$ is formed. ${ }^{2}$ In this context, we have recently described the azametallacycles $c i s-\left[\mathrm{L}_{2} \mathrm{PtNH}=\mathrm{C}(\mathrm{Me})\{1-\mathrm{MeCy}(-2 \mathrm{H})\}\right]^{+}$and $c i s-\left[\mathrm{L}_{2^{-}}\right.$ $\mathrm{PtNH}=\mathrm{C}(\mathrm{Me})\{9-\mathrm{MeAd}(-2 \mathrm{H})\}]^{+}\left(\mathrm{L}=\mathrm{PPh}_{3}, \mathrm{PMePh}_{2}\right)$, where the anionic ligands are the deprotonated forms of the amidines shown in Chart 1.

These complexes are formed as the result of a formal insertion of an acetonitrile molecule into a $\mathrm{Pt}-\mathrm{N}$ bond of the $\mathrm{NH}_{2}$-deprotonated nucleobases 1-methylcytosine (1-MeCy)

*To whom correspondence should be addressed. E-mail: bruno.longato@ unipd.it. Tel.: +39049 8275197. Fax: +390498275161.

(1) (a) Kukushkin, V. Y.; Pombeiro, A. J. L. Chem. Rev. 2002, 102, 1771-

1802. (b) Michelin, R. A.; Mozzon, M.; Bertani, R. Coord. Chem. Rev. 1996, 147, 299-338. (c) Reisner, E.; Arion, V. B.; Chioresku, J.; Schmid, W. F. J. Chem. Soc., Dalton Trans. 2008, 2355-2364.

(2) (a) Carmona, D.; Ferrer, J.; Lahoz, F. J.; Oro, L. A.; Lamata, M. P. Organometallics 1996, 15, 5175-5178. (b) Lopez, J.; Santos, A.; Romero, A.; Echavarren, A. M. J. Organomet. Chem. 1993, 443, 221-228.

(3) Longato, B.; Montagner, D.; Bandoli, G.; Zangrando, E. Inorg. Chem. 2006, 45, 1805-1814.
Chart 1. Neutral Forms of the Anionic Ligands Found in Azametallacycle Complexes cis- $\left[\mathrm{L}_{2} \mathrm{PtNH}=\mathrm{C}(\mathrm{Me})\{1-\mathrm{MeCy}(-2 \mathrm{H})\}\right]^{+}$(Right) and cis- $\left[\mathrm{L}_{2} \mathrm{PtNH}=\mathrm{C}(\mathrm{Me})\{9-\mathrm{MeAd}(-2 \mathrm{H})\}\right]^{+}(\mathrm{Left})\left(\mathrm{L}=\mathrm{PPh}_{3}, \mathrm{PMePh}_{2}\right)$<smiles>CC(=N)/N=c1\[nH]cnc2c1ncn2C(C)(C)C</smiles><smiles>CC(=N)/N=c1/ccn(C)c(=O)[nH]1</smiles>

and 9-methyladenine (9-MeAd). ${ }^{3}$ As an example, the trinuclear complex cis- $\left[\left(\mathrm{PMePh}_{2}\right)_{2} \mathrm{Pt}\left\{9-\operatorname{MeAd}(-\mathrm{H}), N^{1} N^{6}\right\}\right]_{3}{ }^{3+}$, containing bridging 9-methyladeninate ligands, ${ }^{4}$ dissolved in $\mathrm{CH}_{3} \mathrm{CN}$, gives the species $c i s-\left[\left(\mathrm{PMePh}_{2}\right)_{2} \mathrm{PtNH}=\mathrm{C}(\mathrm{Me})\{9-\right.$ $\operatorname{MeAd}(-\mathrm{H})\}]^{+}$, as shown in Chart 2.

The reaction requires (i) the formation of a mononuclear species cis- $\left[\mathrm{L}_{2} \mathrm{Pt}(\mathrm{N} \equiv \mathrm{C}-\mathrm{Me})\{9-\mathrm{MeAd}(-\mathrm{H})\}\right]^{+}$containing a

(4) Longato, B.; Pasquato, L.; Mucci, A.; Schenetti, L.; Zangrando, E. Inorg. Chem. 2003, 42, 7861-7871. 


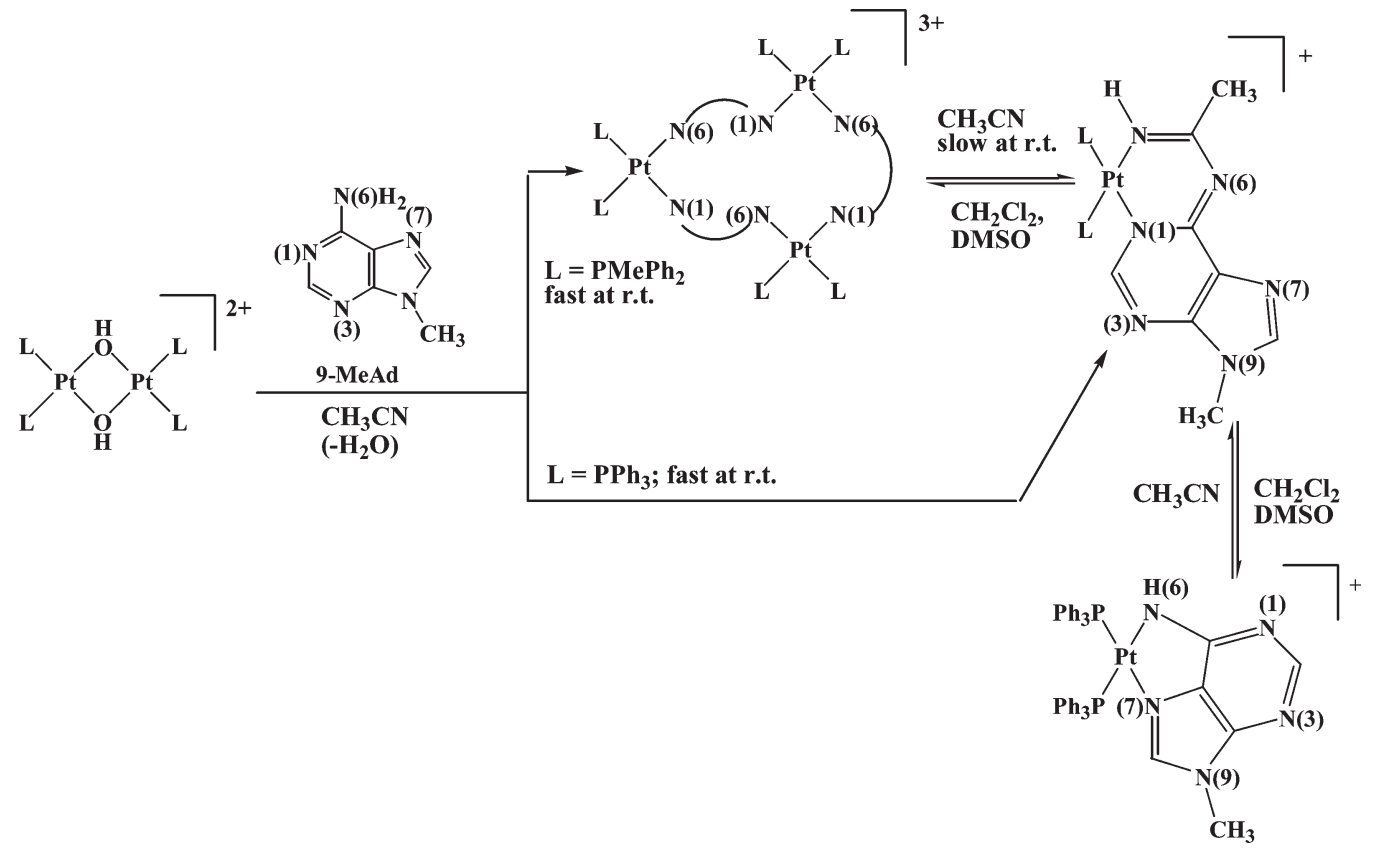

metal-coordinated solvent nitrile and the monodentate anionic 9-MeAd $(-\mathrm{H})$, likely $\mathrm{N}^{1}$-platinated, and (ii) the intramolecular nucleophilic attack at the carbon atom of the $\mathrm{CH}_{3} \mathrm{CN}$ ligand by the N6 imino atom of the adeninate ion with concomitant migration of the $\mathrm{N} 6 H$ proton at the acetonitrile nitrogen atom to give the cyclic amidine complex. The trinuclear complex, in turn, was isolated by reacting the hydroxo complex cis-[( $\left.\left.\mathrm{PMePh}_{2}\right)_{2} \mathrm{Pt}(\mu-\mathrm{OH})\right]_{2}{ }^{2+}$ with $9-\mathrm{MeAd}$, in a $\mathrm{CH}_{3} \mathrm{CN}$ solution, in which the condensation reaction occurs quickly. ${ }^{4}$ In the same experimental conditions, the hydroxo complex cis- $\left[\left(\mathrm{PPh}_{3}\right)_{2} \mathrm{Pt}(\mu-\mathrm{OH})\right]_{2}{ }^{2+}$ leads directly to the insertion product cis- $\left[\left(\mathrm{PPh}_{3}\right)_{2} \mathrm{PtNH}=\mathrm{C}(\mathrm{Me})\{9-\mathrm{MeAd}(-2 \mathrm{H})\}\right]^{+}$.

The adenine derivatives $c i s-\left[\mathrm{L}_{2} \mathrm{PtNH}=\mathrm{C}(\mathrm{Me})\{9-\mathrm{MeAd}-\right.$ $(-2 \mathrm{H})\}]^{+}$, in chlorinated solvents, release reversibly the inserted $\mathrm{CH}_{3} \mathrm{CN}$ molecule to form the trinuclear cyclic species cis- $\left[\mathrm{L}_{2} \mathrm{Pt}\{9-\mathrm{MeAd}(-\mathrm{H})\}\right]_{3}{ }^{3+}$ when $\mathrm{L}$ is $\mathrm{PMePh}_{2}$ or the mononuclear chelate adeninate complex cis- $\left[\left(\mathrm{PPh}_{3}\right)_{2} \mathrm{Pt}\{9-\mathrm{MeAd}-\right.$ $\left.\left.(-\mathrm{H}), N^{6} N^{7}\right\}\right]^{+}$when $\mathrm{L}$ is $\mathrm{PPh}_{3}{ }^{5}$

In spite of the large number of studies dealing with metal nucleobase complexes, ${ }^{6}$ coupling reactions of nitriles with the exocyclic nitrogen atoms of 9-MeAd and 1-MeCy have only a precedent in the literature. ${ }^{7}$

In this paper, we report the coupling reactions of benzonitrile with 1-MeCy and 9-MeAd, occurring when the hydroxo complexes cis- $\left[\mathrm{L}_{2} \mathrm{Pt}(\mu-\mathrm{OH})\right]_{2}\left(\mathrm{NO}_{3}\right)_{2}\left\{\mathrm{~L}=\mathrm{PPh}_{3}, \mathrm{PMePh}_{2}\right.$, $1 / 2$ dppe [dppe $=1,2$-bis(diphenylphosphino)ethane] $\}$ react in a PhCN solution. The insertion products cis- $\left[\mathrm{L}_{2} \mathrm{PtNH}=\right.$ $\mathrm{C}(\mathrm{Ph})\{1-\mathrm{MeCy}(-2 \mathrm{H})\}] \mathrm{NO}_{3}\left(\mathrm{~L}=\mathrm{PPh}_{3}, \mathbf{1} ; \mathrm{PMePh}_{2}, \mathbf{2}\right.$; $1 / 2$ dppe, 3$)$ and cis- $\left[\mathrm{L}_{2} \mathrm{PtNH}=\mathrm{C}(\mathrm{Ph})\{9-\mathrm{MeAd}(-2 \mathrm{H})\}\right] \mathrm{NO}_{3}(\mathrm{~L}=$ $\left.\mathrm{PPh}_{3}, 4 ; \mathrm{PMePh}_{2}, 5\right)$ have been isolated as pure compounds and fully characterized by multinuclear NMR studies, and the molecular structures of $\mathbf{2}$ and $\mathbf{4}$ have been confirmed by single-crystal $\mathrm{X}$-ray analyses. Unlike the $\mathrm{CH}_{3} \mathrm{CN}$ analogues,

(5) Montagner, D.; Longato, B. Inorg. Chim. Acta 2008, 361, 1676-1680. (6) (a) Zangrando, E.; Pichierri, F.; Randaccio, L.; Lippert, B. Coord. Chem. Rev. 1996, 156, 275-332. (b) Lippert, B. Coord. Chem. Rev. 2000, 200-202, 487-516.

(7) Pearson, C.; Beauchamp, A. L. Inorg. Chem. 1998, 37, 1242-1248. these compounds are indefinitely stable in a solution of dimethyl sulfoxide (DMSO) or chlorinated solvents; i.e., the formal insertion of $\mathrm{PhCN}$ into the $\mathrm{Pt}-\mathrm{N}$ bond of the nucleobase is irreversible. Moreover, the protonation of the anionic ligands in $\mathbf{3}$ and $\mathbf{4}$ has been examined. The reaction, carried out by dissolving $\mathbf{4}$ in acetylacetone (Hacac), causes the quantitative formation of the complex cis- $\left[\left(\mathrm{PPh}_{3}\right)_{2} \mathrm{Pt}\right.$ (acac) $] \mathrm{NO}_{3}$, while the replacement of the benzimidamide ligand occurs only partially in the case of complex $\mathbf{3}$.

\section{Experimental Section}

Instrumentation and Materials. The NMR spectra were obtained in a solution of various solvents at $300 \mathrm{~K}$ on a Bruker AVANCE $300 \mathrm{MHz}$ for ${ }^{1} \mathrm{H}$ and ${ }^{31} \mathrm{P}$ NMR $\left(v_{\mathrm{o}} 300.13\right.$ and 121.5 $\mathrm{MHz}$, respectively) and on a Bruker 400 AMX-WB spectrometer for ${ }^{15} \mathrm{NNMR}\left(v_{\mathrm{O}} 40.6 \mathrm{MHz}\right) . \delta$ are in parts per million and $J$ in hertz. The ${ }^{1} \mathrm{H},{ }^{31} \mathrm{P}$, and ${ }^{15} \mathrm{~N}$ NMR chemical shift values were referenced to internal $\mathrm{Me}_{4} \mathrm{Si}$, external $85 \%$ aqueous $\mathrm{H}_{3} \mathrm{PO}_{4}$, and $\mathrm{CH}_{3} \mathrm{NO}_{2}$, respectively. The ${ }^{15} \mathrm{~N}$ NMR parameters were obtained through HMBC experiments. The heteronuclear Overhauser enhancement spectroscopy (HOESY) experiments were obtained by using a Bruker QNP probe operating in the direct acquisition mode at $161.98 \mathrm{MHz}$ for ${ }^{31} \mathrm{P} \mathrm{NMR}$ and $400.13 \mathrm{MHz}$ for ${ }^{1} \mathrm{H}$ NMR on a $9.4 \mathrm{~T}$ field. The ${ }^{31} \mathrm{P}$ NMR experiments carried out in nondeuterated solvents, Hacac and hexafluoroacetylacetonate (hfHacac), were recorded with an insert of $\mathrm{D}_{2} \mathrm{O}$ for the instrumental lock. The labeling of the proton resonances follows the X-ray numbering scheme used for $\mathbf{2}$ and $\mathbf{4}$.

cis- $\left[\left(\mathrm{PMePh}_{2}\right)_{2} \mathrm{Pt}(\mu-\mathrm{OH})\right]_{2}\left(\mathrm{NO}_{3}\right)_{2},{ }^{4}$ cis- $[(\mathrm{dppe}) \mathrm{Pt}(\mu-\mathrm{OH})]_{2}\left(\mathrm{NO}_{3}\right)_{2},{ }^{8}$ and $1-\mathrm{MeCy}^{9}$ were prepared as previously reported. $9-\mathrm{MeAd}$ and all of the solvents were Aldrich products.

Synthetic Work. 1. cis- $\left[\left(\mathrm{PPh}_{3}\right)_{2} \mathbf{P t N H}=\mathbf{C}(\mathbf{P h})\{1-\mathrm{MeCy}-\right.$ $(-\mathbf{2 H})\}] \mathbf{N O}_{3}(\mathbf{1})$. A mixture of cis- $\left[\left(\mathrm{PPh}_{3}\right)_{2} \mathrm{Pt}(\mu-\mathrm{OH})\right]_{2}\left(\mathrm{NO}_{3}\right)_{2}$ (410 mg, $\left.2.57 \times 10^{-1} \mathrm{mmol}\right)$ and $1-\mathrm{MeCy}\left(64.2 \mathrm{mg}, 5.13 \times 10^{-1}\right.$ $\mathrm{mmol})$ in $\mathrm{PhCN}(20 \mathrm{~mL})$ was stirred at room temperature for ca. $4 \mathrm{~h}$. The resulting yellow solution was filtered to remove trace amounts of a solid. The addition of $\mathrm{Et}_{2} \mathrm{O}(100 \mathrm{~mL})$ to the filtrate

(8) Li, J. J.; Li, W.; Sharp, P. R. Inorg. Chem. 1996, 35, 604-613.

(9) Kistenmacher, T. J.; Rossi, M.; Caradonna, J. P.; Marzilli, L. G. $A d v$. Mol. Relax. Interact. Processes 1979, 15, 119-133. 
afforded $\mathbf{1} \cdot \mathrm{Et}_{2} \mathrm{O}$ as a pale-yellow solid, which was isolated and dried under vacuum (yield 96\%). Elem anal. Calcd for $\mathrm{C}_{52} \mathrm{H}_{51} \mathrm{~N}_{5} \mathrm{O}_{5} \mathrm{P}_{2} \mathrm{Pt}$ : C, 57.67; H, 4.76; N, 6.46. Found: C, 57.80; $\mathrm{H}, 4.85 ; \mathrm{N}, 6.55$. ${ }^{1} \mathrm{H} \mathrm{NMR}$ in $\mathrm{CDCl}_{3}: \delta 7.70-7.24$ (c m, viz. complex multiplet, $35 \mathrm{H}, \mathrm{Ph}-\mathrm{CN}$ and $\left.\mathrm{PPh}_{3}\right), 7.14\left(\mathrm{~d},{ }^{3} J_{\mathrm{HH}}=\right.$ $7.08,1 \mathrm{H}, \mathrm{H} 6), 6.22\left(\mathrm{dd},{ }^{3} J_{\mathrm{HH}}=7.08,{ }^{5} J_{\mathrm{HP}}=1.52,1 \mathrm{H}, \mathrm{H} 5\right), 6.05$ (br s, $1 \mathrm{H}, \mathrm{N} 2 \mathrm{H}), 2.76$ (s, 3H, N1CH $\left.{ }_{3}\right) .{ }^{1} \mathrm{H}$ NMR in DMSO- $d_{6}: \delta$ $7.84-7.22\left(\mathrm{c} \mathrm{m}, 35 \mathrm{H}, \mathrm{Ph}-\mathrm{CN}\right.$ and $\left.\mathrm{PPh}_{3}\right), 7.21\left(\mathrm{~d},{ }^{3} J_{\mathrm{HH}}=7.75\right.$, $1 \mathrm{H}, \mathrm{H} 6), 6.12\left(\mathrm{~d},{ }^{3} J_{\mathrm{HH}}=7.75,1 \mathrm{H}, \mathrm{H} 5\right), 6.60($ br s, $1 \mathrm{H}, \mathrm{N} 2 \mathrm{H})$, $2.58\left(\mathrm{~s}, 3 \mathrm{H}, \mathrm{N} \mathrm{CH}_{3}\right)$. The presence of one molecule of $\mathrm{Et}_{2} \mathrm{O}$ was confirmed by ${ }^{1} \mathrm{H}$ NMR.

The ${ }^{31} \mathrm{P}\left\{{ }^{1} \mathrm{H}\right\}$ NMR data of complexes $\mathbf{1 - 5}$ in different solvents are reported in Table 2.

2. cis $-\left[\left(\mathrm{PMePh}_{2}\right)_{2} \mathrm{PtNH}=\mathrm{C}(\mathrm{Ph})\{1-\mathrm{MeCy}(-2 \mathrm{H})\}\right] \mathrm{NO}_{3}(2) . \mathrm{A}$ mixture of cis-[(PMePh$\left.)_{2} \mathrm{Pt}(\mu-\mathrm{OH})\right]_{2}\left(\mathrm{NO}_{3}\right)_{2}(210 \mathrm{mg}, 1.55 \times$ $\left.10^{-1} \mathrm{mmol}\right)$ and $1-\mathrm{MeCy}\left(38.9 \mathrm{mg}, 3.1 \times 10^{-1} \mathrm{mmol}\right)$ in $\mathrm{PhCN}$ $(15 \mathrm{~mL})$ was stirred at room temperature for ca. $2 \mathrm{~h}$. The addition of $\mathrm{Et}_{2} \mathrm{O}(90 \mathrm{~mL})$ to the resulting solution afforded a pale-yellow solid, which was isolated by filtration and dried under vacuum. Dissolution of the crude product in $\mathrm{PhCN}$ and vapor diffusion of $\mathrm{Et}_{2} \mathrm{O}$ at room temperature afforded crystals of $2 \cdot 0.5 \mathrm{Et}_{2} \mathrm{O}$ suitable for X-ray analyses (yield $79 \%$ ). Elem anal. Calcd for $\mathrm{C}_{40} \mathrm{H}_{42} \mathrm{~N}_{5} \mathrm{O}_{4.5} \mathrm{P}_{2} \mathrm{Pt}$ : C, 52.12; H, 4.60; N, 7.59. Found: $\mathrm{C}, 52.35 ; \mathrm{H}, 4.52 ; \mathrm{N}, 7.66 .{ }^{1} \mathrm{H}$ NMR in $\mathrm{CD}_{2} \mathrm{Cl}_{2}: \delta 7.65-7.23$ (c m, 25H, Ph-CN and $\left.\mathrm{PPh}_{2}\right), 6.96\left(\mathrm{~d},{ }^{3} \mathrm{~J}_{\mathrm{HH}}=7.17,1 \mathrm{H}, \mathrm{H} 6\right)$, $6.15\left(\mathrm{~d},{ }^{3} J_{\mathrm{HH}}=7.17,1 \mathrm{H}, \mathrm{H} 5\right), 6.07(\mathrm{br} \mathrm{s}, 1 \mathrm{H}, \mathrm{N} 2 \mathrm{H}), 2.68(\mathrm{~s}, 3 \mathrm{H}$, $\left.\mathrm{N} \mathrm{CH}_{3}\right), 2.01$ (br d, $\left.{ }^{2} J_{\mathrm{HP}} 8.51,3 \mathrm{H}, \mathrm{PMe}\right), 1.86\left(\mathrm{~d},{ }^{2} J_{\mathrm{HP}} 8.51,3 \mathrm{H}\right.$, $\mathrm{PMe}) .{ }^{1} \mathrm{H}$ NMR in $\mathrm{CD}_{2} \mathrm{Cl}_{2}\left(-75^{\circ} \mathrm{C}\right): \delta 7.86-6.91(\mathrm{c} \mathrm{m}, 52 \mathrm{H}$, $\mathrm{Ph}-\mathrm{CN}, \mathrm{H} 6$, and $\left.\mathrm{PPh}_{2}\right)$; the main conformer, $\delta 6.10\left(\mathrm{~d},{ }^{3} J_{\mathrm{HH}}=\right.$ 6.43, 1H, H5), 5.88 (br s, 1H, N2H), 2.63 (s, 3H, N1CH $\left.\mathrm{N}_{3}\right), 1.77$ $\left(\mathrm{d},{ }^{2} J_{\mathrm{HP}}=8.91,3 \mathrm{H}, \mathrm{PMe}\right), 1.30\left(\mathrm{~d},{ }^{2} J_{\mathrm{HP}}=7.65,3 \mathrm{H}, \mathrm{PMe}\right)$; the minor conformer, $\delta 6.17\left(\mathrm{~d},{ }^{2} J_{\mathrm{HP}}=6.58,1 \mathrm{H}, \mathrm{H} 5\right), 5.97(\mathrm{br} \mathrm{s}$, $1 \mathrm{H}, \mathrm{N} 2 \mathrm{H}), 2.58\left(\mathrm{~s}, 3 \mathrm{H}, \mathrm{N} 1 \mathrm{CH}_{3}\right), 2.70\left(\mathrm{~d},{ }^{2} J_{\mathrm{HP}}=9.70,3 \mathrm{H}, \mathrm{PMe}\right)$, $2.03\left(\mathrm{~d},{ }^{2} J_{\mathrm{HP}}=8.91,3 \mathrm{H}, \mathrm{PMe}\right) .{ }^{1} \mathrm{H}$ NMR in DMSO- $d_{6}: \delta$ $7.68-7.30\left(\mathrm{c} \mathrm{m}, 25 \mathrm{H}, \mathrm{Ph}-\mathrm{CN}\right.$ and $\left.\mathrm{PPh}_{2}\right), 7.18\left(\mathrm{~d},{ }^{3} J_{\mathrm{HH}}=7.62\right.$, $1 \mathrm{H}, \mathrm{H} 6), 6.11\left(\mathrm{~d},{ }^{3} J_{\mathrm{HH}}=7.62,1 \mathrm{H}, \mathrm{H} 5\right), 6.42($ br s, $1 \mathrm{H}, \mathrm{N} 2 \mathrm{H})$, $2.61\left(\mathrm{~s}, 3 \mathrm{H}, \mathrm{N} 1 \mathrm{CH}_{3}\right), 2.08\left(\mathrm{br} \mathrm{d},{ }^{2} J_{\mathrm{HP}}=10.92,6 \mathrm{H}, \mathrm{PMe}\right)$. The presence of $\mathrm{Et}_{2} \mathrm{O}$ was confirmed by ${ }^{1} \mathrm{H}$ NMR.

3. cis- $[($ dppe $) \mathrm{PtNH}=\mathrm{C}(\mathrm{Ph})\{1-\mathrm{MeCy}(-2 \mathrm{H})\}] \mathrm{NO}_{3}(3)$. A mixture of $c i s-[(\mathrm{dppe}) \mathrm{Pt}(\mu-\mathrm{OH})]_{2}\left(\mathrm{NO}_{3}\right)_{2}\left(100 \mathrm{mg}, 7.43 \times 10^{-2}\right.$ $\mathrm{mmol})$ and $1-\mathrm{MeCy}\left(18.6 \mathrm{mg}, 1.49 \times 10^{-1} \mathrm{mmol}\right)$ in $\mathrm{PhCN}$ $(8 \mathrm{~mL})$ was stirred at room temperature for 1 day. The resulting yellow solution was filtered to eliminate trace amounts of a dark solid. The addition of $\mathrm{Et}_{2} \mathrm{O}(70 \mathrm{~mL})$ to the filtrate afforded a pale-yellow precipitate, which was isolated and dried under vacuum. The isolated solid corresponds to the formula cis- $[($ dppe $) \mathrm{PtNH}=\mathrm{C}(\mathrm{Ph})\{1-\mathrm{MeCy}(-2 \mathrm{H})\}] \mathrm{NO}_{3}$ (yield $65 \%$ ). Elem anal. Calcd for $\mathrm{C}_{38} \mathrm{H}_{35} \mathrm{~N}_{5} \mathrm{O}_{4} \mathrm{P}_{2} \mathrm{Pt}$ : C, 51.70; $\mathrm{H}, 4.00 ; \mathrm{N}$, 7.93. Found: $\mathrm{C}, 51.92 ; \mathrm{H}, 3.96 ; \mathrm{N}, 7.98 .{ }^{1} \mathrm{H} \mathrm{NMR}$ in $\mathrm{CD}_{2} \mathrm{Cl}_{2}: \delta$ $7.78-7.31\left(\mathrm{c} \mathrm{m}, 25 \mathrm{H}, \mathrm{Ph}-\mathrm{CN}\right.$ and $\left.\mathrm{PPh}_{2}\right), 7.19\left(\mathrm{~d},{ }^{3} \mathrm{~J}_{\mathrm{HH}}=7.08\right.$, $1 \mathrm{H}, \mathrm{H} 6), 6.21\left(\mathrm{~d},{ }^{3} J_{\mathrm{HH}}=7.08,1 \mathrm{H}, \mathrm{H} 5\right), 7.01(\mathrm{br} \mathrm{s}, 1 \mathrm{H}, \mathrm{N} 2 \mathrm{H}), 2.78$ $\left(\mathrm{s}, 3 \mathrm{H}, \mathrm{N}^{-\mathrm{CH}_{3}}\right), 2.53-2.23\left(\mathrm{c} \mathrm{m}, 4 \mathrm{H}, \mathrm{P}\left(\mathrm{CH}_{2}\right)_{2}\right) .{ }^{1} \mathrm{H} \mathrm{NMR}$ in DMSO- $d_{6}: \delta 7.71-7.25\left(\mathrm{c} \mathrm{m}, 25 \mathrm{H}, \mathrm{Ph}-\mathrm{CN}\right.$ and $\left.\mathrm{PPh}_{2}\right), 7.01(\mathrm{~d}$, $\left.{ }^{3} J_{\mathrm{HH}}=7.48,1 \mathrm{H}, \mathrm{H} 6\right), 6.42\left(\mathrm{~d},{ }^{3} J_{\mathrm{HH}}=7.48,1 \mathrm{H}, \mathrm{H} 5\right), 6.53(\mathrm{br} \mathrm{s}$, $1 \mathrm{H}, \mathrm{N} 2 \mathrm{H}), 2.98$ (s, 3H, N1CH $)_{3}, 2.65-2.31\left(\mathrm{c} \mathrm{m}, 4 \mathrm{H}, \mathrm{P}\left(\mathrm{CH}_{2}\right)_{2}\right)$.

4. cis- $\left[\mathrm{L}_{2} \mathbf{P t N H}=\mathrm{C}(\mathrm{Ph})\{\mathbf{9}-\mathrm{MeAd}(-\mathbf{2 H})\}\right] \mathrm{NO}_{3}\left(\mathrm{~L}=\mathbf{P P h}_{3}, \mathbf{4}\right.$; $\left.\mathbf{P M e P h}_{2}, \mathbf{5}\right)$. A mixture of $c i s-\left[\left(\mathrm{PPh}_{3}\right)_{2} \mathrm{Pt}(\mu-\mathrm{OH})\right]_{2}\left(\mathrm{NO}_{3}\right)_{2}$ $\left(92.1 \mathrm{mg}, 5.7 \times 10^{-2} \mathrm{mmol}\right)$ and $9-\operatorname{MeAd}\left(17 \mathrm{mg}, 1.2 \times 10^{-1}\right.$ $\mathrm{mmol}$ ) in $\mathrm{PhCN}(5 \mathrm{~mL})$ was stirred at room temperature for ca. $48 \mathrm{~h}$. The addition of $\mathrm{Et}_{2} \mathrm{O}(20 \mathrm{~mL})$ to the resulting solution afforded a pale-yellow solid, which was isolated by filtration and dried under vacuum. Dissolution of the crude product in $\mathrm{PhCN}$, followed by precipitation with $\mathrm{Et}_{2} \mathrm{O}$ at room temperature, afforded microcrystals of $\mathbf{4}$ having the composition cis- $\left[\left(\mathrm{PPh}_{3}\right)_{2-}\right.$ $\mathrm{PtNH}=\mathrm{C}(\mathrm{Ph})\{9-\mathrm{MeAd}(-2 \mathrm{H})\}] \mathrm{NO}_{3} \cdot \mathrm{H}_{2} \mathrm{O}$ (yield $83 \%$ ). Elem anal. Calcd for $\mathrm{C}_{49} \mathrm{H}_{43} \mathrm{~N}_{7} \mathrm{O}_{4} \mathrm{P}_{2} \mathrm{Pt}$ : C, 56.00; H, 4.13; N, 9.32. Found: $\mathrm{C}, 55.88 ; \mathrm{H}, 4.20 ; \mathrm{N}, 9.38$. The presence of water in the isolated solid was confirmed by ${ }^{1} \mathrm{H}$ NMR, although the crystals, obtained by vapor diffusion of $\mathrm{Et}_{2} \mathrm{O}$ into a $\mathrm{PhCN}$ solution used for single-crystal X-ray analyses, appear to be an anhydrous product. ${ }^{1} \mathrm{H}$ NMR in $\mathrm{CDCl}_{3}: \delta 7.57-7.20(\mathrm{c} \mathrm{m}$, $35 \mathrm{H}, \mathrm{Ph}-\mathrm{CN}$ and $\mathrm{PPh}_{3}$ ), 8.28 (s, 1H, H2), 7.95 (s, 1H, H8), 6.32 (br dd, $1 \mathrm{H}, \mathrm{N} 2 \mathrm{H}), 3.60$ (s, 3H, N1CH $\left.{ }_{3}\right) .{ }^{1} \mathrm{H}$ NMR in DMSO- $d_{6}$ : $\delta 7.71-7.19$ (c m, 35H, $\mathrm{Ph}-\mathrm{CN}$ and $\left.\mathrm{PPh}_{3}\right), 8.26(\mathrm{~s}, 1 \mathrm{H}, \mathrm{H} 2), 8.15$ (s, 1H, H8), 6.29 (br s, 1H, N2H), 3.50 (s, 3H, N1CH ${ }_{3}$ ).

With a similar procedure, complex $\mathbf{5}$ was prepared by reacting cis- $\left[\left(\mathrm{PMePh}_{2}\right)_{2} \mathrm{Pt}(\mu-\mathrm{OH})\right]_{2}\left(\mathrm{NO}_{3}\right)_{2}\left(20 \mathrm{mg}, 1.4 \times 10^{-2} \mathrm{mmol}\right)$ and 9-MeAd (4.3 mg, $\left.2.8 \times 10^{-2} \mathrm{mmol}\right)$ in PhCN $(2 \mathrm{~mL})$. The ${ }^{31} \mathrm{P}$ NMR of the reacting mixture indicated an almost quantitative formation of 5. The ${ }^{31} \mathrm{P}$ NMR in $\mathrm{PhCN}$ is an $\mathrm{AB}$ multiplet at $\delta \mathrm{P}_{\mathrm{A}}=-2.80\left({ }^{1} J_{\mathrm{PPt}}=3242\right)$ and $\delta \mathrm{P}_{\mathrm{B}}=-3.30\left({ }^{1} J_{\mathrm{PPt}}=3222\right)$. The addition of $\mathrm{Et}_{2} \mathrm{O}$ formed a yellow solid, which was isolated and further analyzed by ${ }^{1} \mathrm{H}$ and ${ }^{31} \mathrm{P}$ NMR in $\mathrm{CDCl}_{3}$. ${ }^{1} \mathrm{H}$ NMR in $\mathrm{CDCl}_{3}: \delta 7.68-7.24\left(\mathrm{c} \mathrm{m}, 25 \mathrm{H}, \mathrm{Ph}-\mathrm{CN}\right.$ and $\left.\mathrm{PPh}_{2}\right), 8.22(\mathrm{~s}, 1 \mathrm{H}$, H2), 7.94 (s, 1H, H8), 6.12 (br s, 1H, N2H), 3.66 (s, 3H, N1CH , $^{2}$, $2.16\left(\mathrm{~d},{ }^{2} J_{\mathrm{HP}}=9.00,3 \mathrm{H}, \mathrm{PMe}\right), 1.85\left(\mathrm{~d},{ }^{2} J_{\mathrm{HP}}=9.00,3 \mathrm{H}, \mathrm{PMe}\right)$.

5. cis- $[(\mathbf{d p p e}) \mathbf{P t}(\mathbf{a c a c})] \mathrm{NO}_{3}$. cis- $[(\mathrm{dppe}) \mathrm{Pt}(\mu-\mathrm{OH})]_{2}\left(\mathrm{NO}_{3}\right)_{2}(50$ $\left.\mathrm{mg}, 3.7 \times 10^{-2} \mathrm{mmol}\right)$ was dissolved in $1 \mathrm{~mL}$ of Hacac. The addition of $\mathrm{Et}_{2} \mathrm{O}$ to the resulting solution afforded a white solid, which was recovered by filtration, washed several times with $\mathrm{Et}_{2} \mathrm{O}$, and dried under vacuum for $24 \mathrm{~h}$ (yield $88 \%$ ). Elem anal. Calcd for $\mathrm{C}_{31} \mathrm{H}_{31} \mathrm{NO}_{5} \mathrm{P}_{2} \mathrm{Pt}$ : C, 49.34; $\mathrm{H}, 4.15 ; \mathrm{N}, 1.86$. Found: $\mathrm{C}$, 49.28; $\mathrm{H}, 4.03 ; \mathrm{N}, 1.90 .{ }^{1} \mathrm{H}$ NMR in $\mathrm{CDCl}_{3}: \delta 7.83-7.50(\mathrm{c} \mathrm{m}$, $\left.20 \mathrm{H}, \mathrm{PPh}_{2}\right), 5.67(\mathrm{~s}, 1 \mathrm{H}, \mathrm{CH}(\mathrm{acac})), 2.86\left(\mathrm{~d},{ }^{2} J_{\mathrm{HP}}=11.30,4 \mathrm{H}\right.$, $\left.\mathrm{P}\left(\mathrm{CH}_{2}\right)_{2}\right), 1.98\left(\mathrm{~s}, 6 \mathrm{H}, \mathrm{CH}_{3}(\right.$ acac $\left.)\right) .{ }^{31} \mathrm{P}\left\{{ }^{1} \mathrm{H}\right\}$ NMR in $\mathrm{CDCl}_{3}$ : singlet at $\delta 30.26\left({ }^{1} J_{\mathrm{PPt}}=3711\right) .{ }^{31} \mathrm{P}\left\{{ }^{1} \mathrm{H}\right\}$ NMR in Hacac: singlet at $\delta 31.41\left({ }^{1} J_{\mathrm{PPt}}=3879\right)$.

6. cis- $\left[\left(\mathbf{P P h}_{3}\right)_{2} \mathbf{P t}(\mathbf{a c a c})\right] \mathbf{N O}_{3}$. cis- $\left[\left(\mathrm{PPh}_{3}\right)_{2} \mathrm{Pt}(\mu-\mathrm{OH})\right]_{2}\left(\mathrm{NO}_{3}\right)_{2}$ (42.4 mg, $2.65 \times 10^{-2} \mathrm{mmol}$ ) was suspended in $3 \mathrm{~mL}$ of Hacac. In few minutes, a pale-yellow solution was obtained, which was further stirred for $2 \mathrm{~h}$ at room temperature. The addition of $\mathrm{Et}_{2} \mathrm{O}(30 \mathrm{~mL})$ afforded a white solid, which was recovered by filtration, washed several times with $\mathrm{Et}_{2} \mathrm{O}$, and dried under vacuum (yield $82 \%$ ). Elem anal. Calcd for $\mathrm{C}_{41} \mathrm{H}_{37} \mathrm{NO}_{5} \mathrm{P}_{2} \mathrm{Pt}$ : C, 55.91; H, 4.24; N, 1.59. Found: C, 55.93; H, 4.30; N, $1.56 .{ }^{1} \mathrm{H}$ NMR in $\mathrm{CDCl}_{3}: \delta 7.50-7.26\left(\mathrm{c} \mathrm{m}, 30 \mathrm{H}, \mathrm{PPh}_{3}\right), 5.59(\mathrm{~s}, 1 \mathrm{H}$, $\mathrm{CH}(\mathrm{acac})), 1.51\left(\mathrm{~s}, 6 \mathrm{H}, \mathrm{CH}_{3}\right.$ (acac)). ${ }^{31} \mathrm{P}\left\{{ }^{1} \mathrm{H}\right\} \mathrm{NMR}$ in $\mathrm{CDCl}_{3}$ : singlet at $\delta 8.65\left({ }^{1} J_{\mathrm{PPt}}=3850\right) .{ }^{31} \mathrm{P}\left\{{ }^{1} \mathrm{H}\right\}$ NMR in Hacac: singlet at $\delta 9.09\left({ }^{1} J_{\mathrm{PPt}}=3868\right)$.

X-ray Structure Determinations. Diffraction data for compounds $\mathbf{2}$ and $\mathbf{4}$ were collected at room temperature on a Nonius DIP- $1030 \mathrm{H}$ system with Mo K $\alpha$ radiation $(\lambda=0.71073 \AA)$. Cell refinement, indexing, and scaling of the data set were carried out using programs Denzo ${ }^{10}$ and Scalepack. ${ }^{10}$ The structures were solved by direct methods and subsequent Fourier analyses ${ }^{11}$ and refined by the full-matrix least-squares method based on $F^{2}$ with all observed reflections. ${ }^{11}$ The $\Delta F$ map of 2 revealed a molecule of diethyl ether located on a 2-fold axis (isotropically refined atoms, 0.5 occupancy, hydrogen atoms not assigned), while the nitrate anion in $\mathbf{4}$ was found to be disordered over two positions (0.5 occupancy each, isotropically refined atoms with restraints on $\mathrm{N}-\mathrm{O}$ bond distances and angles). All the calculations were performed using $\operatorname{Win} G X$, version 1.80 .05 . $^{12}$ Crystal data and details of refinement are collected in Table 1.

\section{Results and Discussion}

Synthesis of the Complexes cis- $\left[\mathrm{L}_{2} \mathrm{PtNH}=\mathrm{C}(\mathrm{Ph})\{1-\mathrm{MeCy}\right.$ $(-2 \mathrm{H})\}] \mathrm{NO}_{3}\left(\mathrm{~L}=\mathbf{P P h}_{3}, \mathbf{1} ; \mathbf{P M e P h}_{2}, 2 ;{ }^{1} /{ }_{2} \mathrm{dppe}, 3\right)$ and cis- $\left[\mathrm{L}_{2} \mathbf{P t N H}=\mathrm{C}(\mathbf{P h})\{\mathbf{9}-\mathrm{MeAd}(-\mathbf{2 H})\}\right] \mathbf{N O}_{3}\left(\mathrm{~L}=\mathbf{P P h}_{3}, \mathbf{4}\right.$; $\mathbf{P M e P h}, \mathbf{5}$ ). We have recently shown that the hydroxo complex cis-[( $\left.\left.\mathrm{PPh}_{3}\right)_{2} \mathrm{Pt}(\mu-\mathrm{OH})\right]_{2}\left(\mathrm{NO}_{3}\right)_{2}$ reacts with

(10) Otwinowski, Z.; Minor, W. Processing of X-ray Diffraction Data Collected in Oscillation Mode. In Methods in Enzymology; Carter, C. W., Jr., Sweet, R. M., Eds.; Academic Press: New York, 1997; Vol. 276, pp 307-326.

(11) Sheldrick, G. M. Acta Crystallogr. 2008, A64, 112-122.

(12) Farrugia, L. J. J. Appl. Crystallogr. 1999, 32, 837-838. 
Table 1. Crystallographic Data and Details of Structural Refinement Parameters for 2 and 4

\begin{tabular}{|c|c|c|}
\hline & $\mathbf{2} \cdot 0.5 \mathrm{OEt}_{2}$ & 4 \\
\hline formula & $\mathrm{C}_{40} \mathrm{H}_{42} \mathrm{~N}_{5} \mathrm{O}_{4.50} \mathrm{P}_{2} \mathrm{Pt}$ & $\mathrm{C}_{49} \mathrm{H}_{41} \mathrm{~N}_{7} \mathrm{O}_{3} \mathrm{P}_{2} \mathrm{Pt}$ \\
\hline fw & 921.82 & 1032.92 \\
\hline cryst syst & monoclinic & triclinic \\
\hline space group & $C 2 / c$ & $P \overline{1}$ \\
\hline$a, \AA$ & $29.932(5)$ & $10.332(3)$ \\
\hline$b, \AA$ & $9.882(2)$ & $13.470(3)$ \\
\hline$c, \AA$ & $28.250(4)$ & $16.910(4)$ \\
\hline$\alpha, \operatorname{deg}$ & & $92.32(2)$ \\
\hline$\beta$, deg & $107.45(3)$ & $99.71(2)$ \\
\hline$\gamma$, deg & & $109.18(3)$ \\
\hline$V, \AA^{3}$ & $7971(2)$ & $2179.2(9)$ \\
\hline$Z$ & 8 & 2 \\
\hline$D_{\text {calcd }}, \mathrm{g} \mathrm{cm}^{-3}$ & 1.536 & 1.574 \\
\hline$\mu, \mathrm{mm}^{-1}$ & 3.648 & 3.345 \\
\hline$F(000)$ & 3688 & 1032 \\
\hline$\theta$ range, deg & $2.18-25.68$ & $1.61-24.71$ \\
\hline reflns collected & 17652 & 30566 \\
\hline reflns unique & 6571 & 6647 \\
\hline reflns $[I>2 \sigma(I)]$ & 3089 & 3559 \\
\hline no. of param & 432 & 556 \\
\hline$R$ (int) & 0.0867 & 0.0560 \\
\hline GOF on $F^{2}$ & 0.787 & 0.765 \\
\hline $\mathrm{R} 1^{a}$ & 0.0421 & 0.0389 \\
\hline $\mathrm{wR} 2^{a}$ & 0.0833 & 0.0724 \\
\hline residuals & $0.916,-0.601$ & $0.803,-0.625$ \\
\hline
\end{tabular}

$1-\mathrm{MeCy}$, in chlorinated solvents, to give the complex cis- $\left[\left(\mathrm{PPh}_{3}\right)_{2} \mathrm{Pt}\left\{1-\mathrm{MeCy}(-\mathrm{H}), N^{4}\right\}\left(1-\mathrm{MeCy}, N^{3}\right)\right] \mathrm{NO}_{3}$ containing a $\mathrm{NH}_{2}$-deprotonated and a neutral cytosine acting as monodentate ligands through the N4 and N3 atoms, respectively. ${ }^{13}$ When the same reaction is carried out in $\mathrm{CH}_{3} \mathrm{CN}$, however, the complex cis- $\left[\left(\mathrm{PPh}_{3}\right)_{2} \mathrm{PtNH}=\right.$ $\mathrm{C}(\mathrm{Me})\{1-\mathrm{MeCy}(-2 \mathrm{H})\}] \mathrm{NO}_{3}$ is obtained in quantitative yield. ${ }^{3}$ The anionic ligand is the deprotonated form of the $\mathrm{N}$-(9-methyl-2-oxo-2,3-dihydro-1 $\mathrm{H}$-pyrimidin-4-ylidene)acetamidine molecule shown in Chart 1 and can be described as the result of the coupling of the metal-activated $\mathrm{CH}_{3} \mathrm{CN}$ molecule with the N4 exocyclic atom of the N3 coordinated cytosine. Analogous reactions, depicted in Chart 3, occur in benzonitrile, and the new metallacycles $\mathbf{1 - 5}$ have been isolated as pure compounds.

The reaction of $c i s-\left[\left(\mathrm{PPh}_{3}\right)_{2} \mathrm{Pt}(\mu-\mathrm{OH})\right]_{2}\left(\mathrm{NO}_{3}\right)_{2}$ with 1$\mathrm{MeCy}$ is fast at room temperature, being complete upon dissolution of the reagents in $\mathrm{PhCN}$, as shown by monitoring of the reaction mixture by ${ }^{31} \mathrm{P}$ NMR. The yield of $\mathbf{1}$ was quantitative, and no intermediates were detectable. A similar behavior was observed with the hydroxo complexes stabilized by $\mathrm{PMePh}_{2}$ and dppe. Compounds 2 and 3 have been isolated in good yield, and no intermediates were identified when the condensation reaction in benzonitrile was monitored by ${ }^{31} \mathrm{P}$ NMR.

In contrast, the suspension of 9-MeAd and cis-[(P$\left.\left.\mathrm{Ph}_{3}\right)_{2} \mathrm{Pt}(\mu-\mathrm{OH})\right]_{2}\left(\mathrm{NO}_{3}\right)_{2}$ in $\mathrm{PhCN}$, in ca. $1 \mathrm{~h}$, forms a pale-yellow solution containing, as the main product, the intermediate species cis-[( $\left.\mathrm{PPh}_{3}\right)_{2} \mathrm{Pt}\{9-\mathrm{MeAd}(-\mathrm{H})$, $\left.\left.N^{6} N^{7}\right\}\right]^{+}$, previously characterized. ${ }^{5}$ This compound, in several hours at room temperature, reacts quantitatively with the solvent, affording 4 . These transformations are clearly evidenced in the ${ }^{31} \mathrm{P}$ NMR spectra of the reaction

(13) Longato, B.; Montagner, D.; Zangrando, E. Inorg. Chem. 2006, 45, 8179-8187. mixture obtained immediately after dissolution of the reagents (Figure 1a) and after $48 \mathrm{~h}$ (Figure 1b).

The $\mathrm{AB}$ multiplets at $\delta 9.2\left({ }^{1} J_{\mathrm{PPt}}=3870\right)$ and 6.0 $\left({ }^{1} J_{\mathrm{PPt}}=3104\right)$ are attributable to the adeninato complex cis- $\left[\left(\mathrm{PPh}_{3}\right)_{2} \mathrm{Pt}\left\{9-\mathrm{MeAd}(-\mathrm{H}), N^{6} N^{7}\right\}\right]^{+}$formed by deprotonation of the exocyclic $\mathrm{NH}_{2}$ group of the nucleobase. This complex, in fact, is the only product formed when the condensation reaction is carried out in chlorinated solvents. ${ }^{5}$ Its dissolution in $\mathrm{PhCN}$ causes the appearance of new $\mathrm{AB}$ multiplets at $\delta 10.9\left({ }^{1} J_{\mathrm{PPt}}=3308\right)$ and $9.9\left({ }^{1} J_{\mathrm{PPt}}=\right.$ $3425)$, due to the product 4 , and the reaction appears complete in several hours at $27^{\circ} \mathrm{C}$.

Complex $\mathbf{4}$ has been isolated as a pure compound and further characterized by multinuclear $\mathrm{NMR}$ in a $\mathrm{CDCl}_{3}$ solution. Attribution of the adenine $\mathrm{H} 2$ and $\mathrm{H} 8$ resonances is supported by ${ }^{1} \mathrm{H}-{ }^{15} \mathrm{~N}$ heteronuclear multiplebond correlation (HMBC) experiments (see Figure S1 in the Supporting Information). The $\mathrm{H} 2$ resonance, at $\delta 8.28$, correlates with the ${ }^{15} \mathrm{~N}$ resonances at $\delta-202$ and -143 , whereas the $\mathrm{H} 8$ proton (at $\delta 7.95$ ) correlates with the ${ }^{15} \mathrm{~N}$ resonances at $\delta-136$ and -224 . The latter resonance, in turn, correlates with the N9 methyl protons. The proton resonance at $\delta 6.32$ appears as a poorly resolved triplet (or a doublet of doublets) due to coupling with the ${ }^{31} \mathrm{P}$ nuclei and is attributed to the N2H proton of the inserted $\mathrm{PhCN}$ molecule. In fact, it correlates with the ${ }^{15} \mathrm{~N}$ resonance at $\delta-243$, with a ${ }^{1} J_{\mathrm{NH}}$ value of ca. $80 \mathrm{~Hz}$. Moreover, in the ${ }^{1} \mathrm{H}-{ }^{31} \mathrm{P}$ HMBC experiment, the adenine $\mathrm{H} 2$ signal exhibits correlations with the ${ }^{31} \mathrm{P}$ resonances, in line with the metalation of the nucleobase at the N1 position. A broad resonance for the $\mathrm{N} 2 \mathrm{H}$ proton, in the range of $\delta 6.05-7.01$, is observed also in the ${ }^{1} \mathrm{H}$ NMR spectra of the 1-MeCy derivatives 1-3. In these complexes, coordination of cytosine at the $\mathrm{N} 3$ atom causes a weak interaction of the pyrimidinic $\mathrm{H} 5$ proton with the phosphine in the trans position, leading to the appearance of this resonance as a well-resolved doublet of doublets in $1\left({ }^{3} J_{\mathrm{H} 5 \mathrm{H} 6}=7.08\right.$ and $\left.{ }^{5} J_{\mathrm{HP}}=1.52\right)$.

It is interesting to note that the reaction with $\mathrm{PhCN}$ (Chart 3) does not occur when the phosphine is $\mathrm{PMe}_{2} \mathrm{Ph}$. Thus, the trinuclear complex cis-[( $\left.\mathrm{PMe}{ }_{2} \mathrm{Ph}\right)_{2} \mathrm{Pt}\{9-\mathrm{MeAd}-$ $(-\mathrm{H})\}]_{3}\left(\mathrm{NO}_{3}\right)_{3}$ can be quantitatively prepared by reacting cis-[( $\left.\left.\mathrm{PMe}_{2} \mathrm{Ph}\right)_{2} \mathrm{Pt}(\mu-\mathrm{OH})\right]_{2}\left(\mathrm{NO}_{3}\right)_{2}$ and 9-MeAd in $\mathrm{CH}_{3} \mathrm{CN},{ }^{14}$ and it remains unchanged upon dissolution in $\mathrm{PhCN}$ even after $12 \mathrm{~h}$ at $50^{\circ} \mathrm{C}$. This lack of reactivity can be interpreted by assuming a high thermodynamic stability of the trinuclear species cis- $\left[\left(\mathrm{PMe}_{2} \mathrm{Ph}\right)_{2} \mathrm{Pt}\right.$ nucleobase $(-\mathrm{H})\}_{3}{ }^{3+}$, which prevents the formation of the key intermediate cis- $\left[\left(\mathrm{PMe}_{2} \mathrm{Ph}\right)_{2} \mathrm{Pt}(\mathrm{N} \equiv \mathrm{CR})\right.$ \{nucleobase $(-\mathrm{H})\}]^{+}$, susceptible to nucleophilic attack of the $\mathrm{N} 4$ cytosine or N6 adenine to the metal-activated nitrile molecule.

Unlike the MeCN analogues (Chart 2), complexes 1-5 are indefinitely stable in a solution of chlorinated solvents or DMSO (at least $24 \mathrm{~h}$ at $50^{\circ} \mathrm{C}$ ).

NMR Behavior of Complex 2. As anticipated for 4 (Figure 1b), the ${ }^{31} \mathrm{P}$ NMR spectra of these insertion products exhibit sharp AB multiplets with well-resolved ${ }^{195} \mathrm{Pt}$ satellites (Table 2 and Figure S2 in the Supporting Information). Only in the case of the $\mathrm{PMePh}_{2}$ complex $\mathbf{2}$ is

(14) Longato., B.; Pasquato, L.; Mucci, A.; Schenetti, L. Eur. J. Inorg. Chem. 2003, 128-137. 
Chart 3
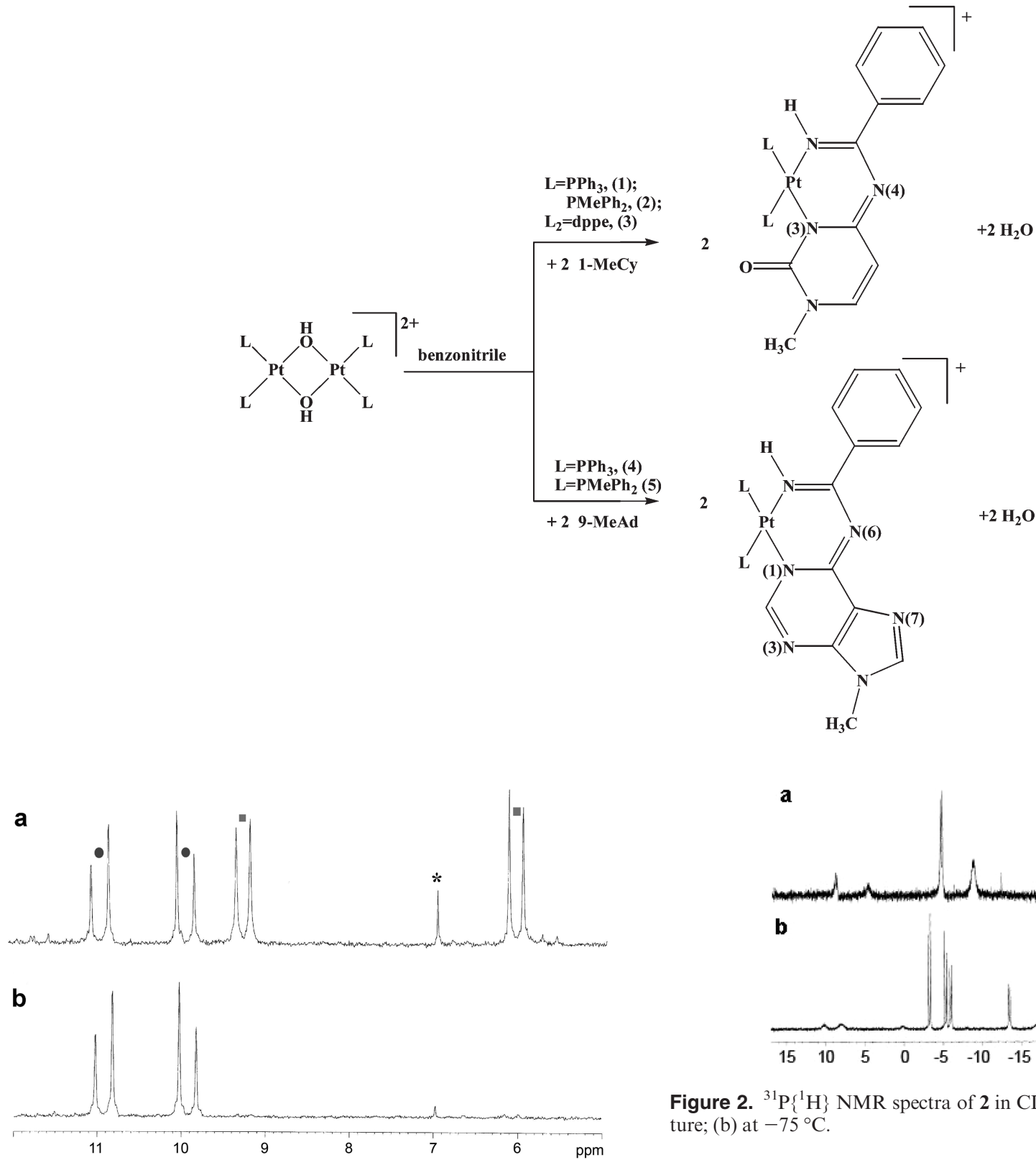

Figure 1. ${ }^{31} \mathrm{P}\left\{{ }^{1} \mathrm{H}\right\}$ NMR spectra (central part) of the reaction between cis- $\left[\left(\mathrm{PPh}_{3}\right)_{2} \mathrm{Pt}(\mu-\mathrm{OH})\right]_{2}\left(\mathrm{NO}_{3}\right)_{2}\left(^{*}\right)$ and $9-\mathrm{MeAd}$ in benzonitrile $\left(\mathrm{D}_{2} \mathrm{O}\right.$ as the inset) at $27^{\circ} \mathrm{C}$ : (a) after $2 \mathrm{~h}$; (b) after $48 \mathrm{~h}$ at room temperature. (苗) Intermediate complex cis-[( $\left.\left.\mathrm{PPh}_{3}\right)_{2} \mathrm{Pt}\left\{9-\mathrm{MeAd}(-\mathrm{H}), N^{6} N^{7}\right\}\right] \mathrm{NO}_{3}$. (•) Insertion product 4 .

the high-field component observed as a broad signal at ambient temperature, whereas the low-field resonances are sharp, as shown in Figure 2a.

At $-75^{\circ} \mathrm{C}$, two sharp $\mathrm{AB}$ spin systems are detected (Figure 2b) whose spectroscopic parameters are collected in Table 2. Similarly, the ${ }^{1} \mathrm{H}$ NMR spectrum of $\mathbf{2}$ at room temperature exhibits a sharp doublet for the methyl protons of one phosphine (at $\delta 1.86,{ }^{2} J_{\mathrm{HP}}=8.51$ ) flanked by ${ }^{195} \mathrm{Pt}$ satellites $\left({ }^{3} J_{\mathrm{HPt}}=\right.$ ca. 30$)$ and a broader one (at $\delta$ $\left.2.01,{ }^{2} J_{\mathrm{HP}}=8.51\right)$. At low temperature $\left(-75^{\circ} \mathrm{C}\right)$, two sets of resonances of comparable relative intensities for each phosphine ligand are detected, as reported in the Experimental Section. A very similar behavior was also observed for the pyrimidinic resonances.

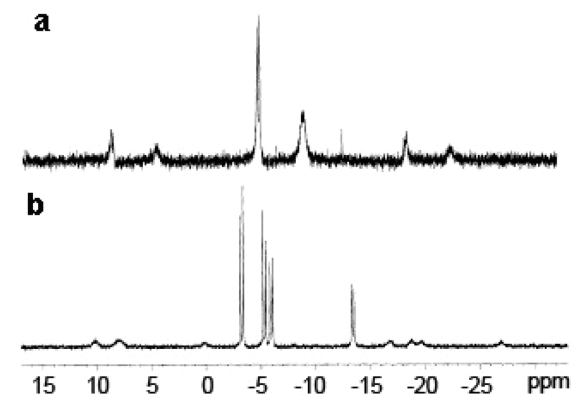

Figure 2. ${ }^{31} \mathrm{P}\left\{{ }^{1} \mathrm{H}\right\}$ NMR spectra of $\mathbf{2}$ in $\mathrm{CD}_{2} \mathrm{Cl}_{2}$ : (a) at room temperature; (b) at $-75^{\circ} \mathrm{C}$.

Table 2. ${ }^{31} \mathrm{P}$ NMR Value of Complexes $\mathbf{1 - 5}$ in Different Solvents and at Different Temperatures ( $\delta$ in ppm and $J$ in $\mathrm{Hz}$ )

\begin{tabular}{clrrl}
\hline compound & \multicolumn{1}{c}{ solvent $(\mathrm{K})$} & \multicolumn{1}{c}{$P_{\mathrm{A}}\left({ }^{1} J_{\mathrm{PPt}}\right)$} & \multicolumn{1}{c}{$P_{\mathrm{B}}\left({ }^{1} J_{\mathrm{PPt}}\right)$} & ${ }^{2} J_{\mathrm{PP}}$ \\
\hline $\mathbf{1}$ & $\mathrm{CDCl}_{3}(298)$ & $9.03(3486)$ & $7.77(3417)$ & 24.9 \\
$\mathbf{1}$ & $\mathrm{DMSO}_{6}(298)$ & $8.22(3509)$ & $7.85(3443)$ & 25.2 \\
$\mathbf{2}$ & $\mathrm{CD}_{2} \mathrm{Cl}_{2}(298)$ & $-5.14(3306)$ & $-9.27(3340)$ & 27.8 \\
$\mathbf{2}$ & $\mathrm{CD}_{2} \mathrm{Cl}_{2}(223)$ & $-3.27(3283)$ & $-5.32(3277)$ & $28.8[56 \%]$ \\
& & $-5.95(3364)$ & $-13.41(3291)$ & $25.9[44 \%]$ \\
$\mathbf{2}$ & $\mathrm{DMSO}_{6}(298)$ & $-4.38(3354)$ & $-8.66(3301)$ & 26.1 \\
$\mathbf{3}$ & $\mathrm{CD}_{2} \mathrm{Cl}_{2}(298)$ & $39.89(3358)$ & $35.57(3408)$ & 11.5 \\
$\mathbf{3}$ & $\mathrm{DMSO}_{6}(298)$ & $38.45(3384)$ & $37.26(3308)$ & 7.17 \\
$\mathbf{4}$ & $\mathrm{CDCl}_{3}(298)$ & $10.95(3263)$ & $10.70(3370)$ & 24.5 \\
$\mathbf{4}$ & $\mathrm{DMSO}_{6}(298)$ & $9.96(3347)$ & $9.28(3436)$ & 25.5 \\
$\mathbf{5}$ & $\mathrm{CDCl}_{3}(298)$ & $-2.97(3240)$ & $-3.45(3149)$ & 27.3
\end{tabular}

These spectral changes are consistent with the occurrence of an equilibrium between preferred conformational arrangements related to a partially restricted rotation around the $\mathrm{Pt}-\mathrm{P}$ bonds. These two conformations arise from the position of the phosphine substituents with respect to the two sides of the coordination plane of 


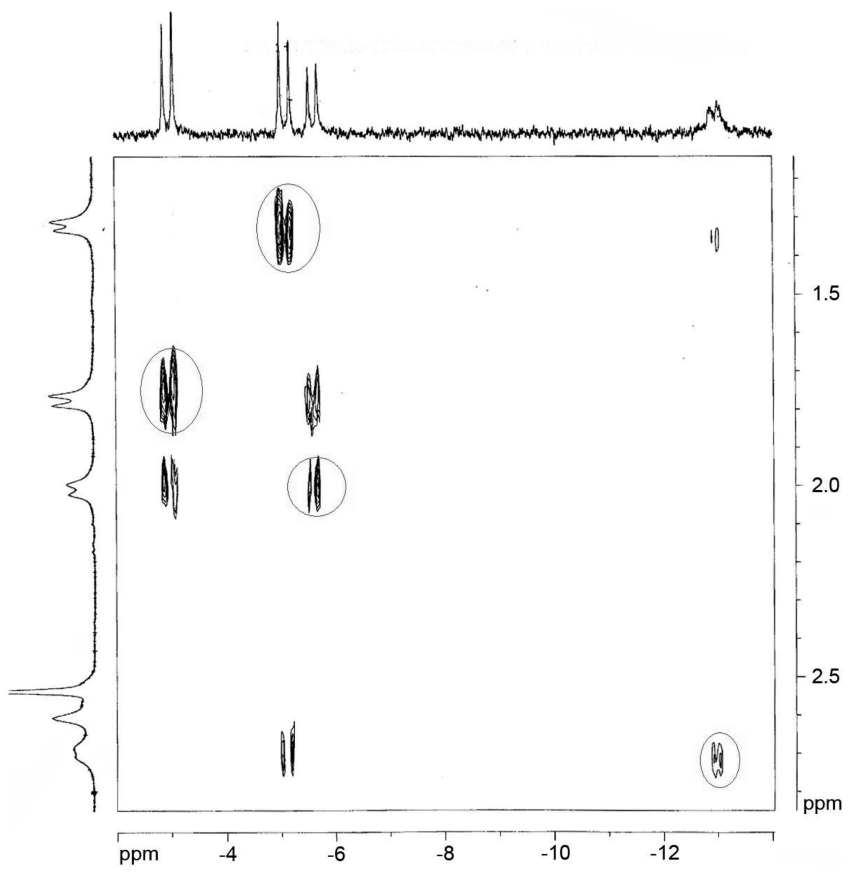

Figure 3. ${ }^{1} \mathrm{H}-{ }^{31} \mathrm{P}$ NMR HOESY spectrum of 2 at $-70{ }^{\circ} \mathrm{C}$ in $\mathrm{CD}_{2} \mathrm{Cl}_{2}$. The circles indicate pure dipolar correlations, with the other cross-peaks being heteronuclear COSY scalar correlations.

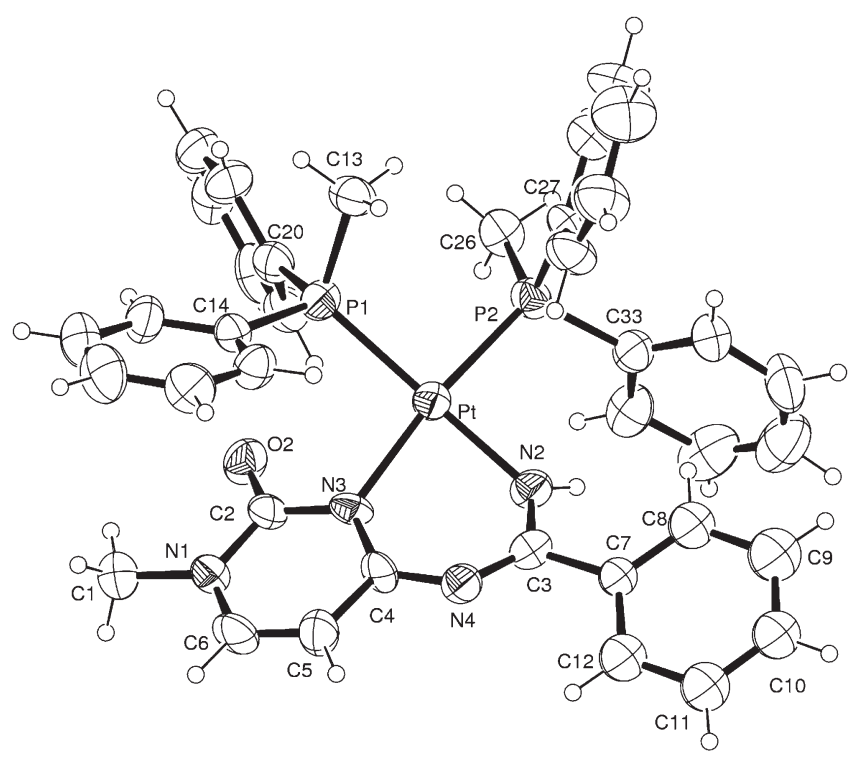

Figure 4. ORTEP drawing ( $40 \%$ ellipsoid probability) of the complex cation of 2 .

the complex: i.e., one presents two phenyls on one side and the methyl on the other, and the second one would have a phenyl and a methyl on the same side, leaving a phenyl on the other. At $-75^{\circ} \mathrm{C}$, the molar ratio between the two conformers is measured to be 56/44. The difference likely arises from a steric interaction of the oxygen atom of 1-MeCy with the ipso carbon of one phenyl ring of the phosphine located in trans to the inserted PhCN molecule and with the phosphorus atom of the same phosphine (see the structure discussion below).

The different line-width values observed at room temperature (Figure 2a) are related to the different $\Delta \delta$ values exhibited by the two AB multiplets (Figure $2 b$ ).

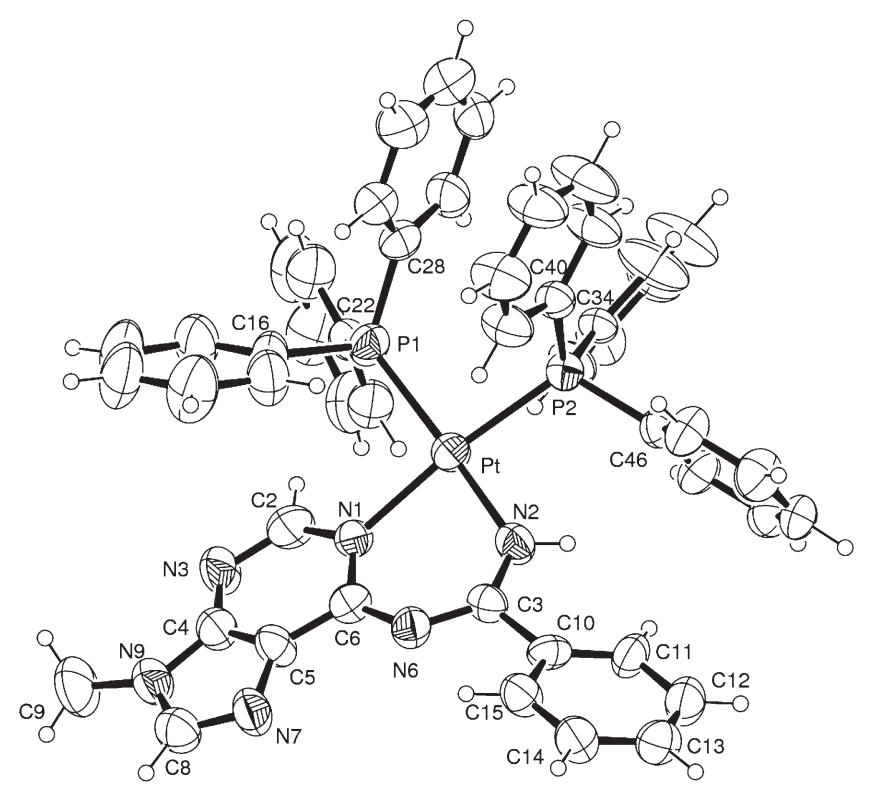

Figure 5. ORTEP drawing ( $40 \%$ ellipsoid probability) of the complex cation of 4 .

Table 3. Selected Bond Lengths ( $\AA$ ) and Angles (deg) for $\mathbf{2}$ and $\mathbf{4}$

\begin{tabular}{|c|c|c|c|}
\hline \multicolumn{2}{|c|}{2} & \multicolumn{2}{|c|}{4} \\
\hline$\overline{\mathrm{Pt}-\mathrm{N} 3}$ & $2.112(7)$ & $\mathrm{Pt}-\mathrm{N} 1$ & $2.116(6)$ \\
\hline $\mathrm{Pt}-\mathrm{N} 2$ & $2.043(6)$ & $\mathrm{Pt}-\mathrm{N} 2$ & $2.010(6)$ \\
\hline $\mathrm{Pt}-\mathrm{P} 1$ & $2.281(2)$ & $\mathrm{Pt}-\mathrm{P} 1$ & $2.313(2)$ \\
\hline $\mathrm{Pt}-\mathrm{P} 2$ & $2.271(2)$ & $\mathrm{Pt}-\mathrm{P} 2$ & $2.280(2)$ \\
\hline $\mathrm{N} 3-\mathrm{C} 4$ & $1.339(10)$ & N1-C6 & $1.388(9)$ \\
\hline $\mathrm{C} 4-\mathrm{N} 4$ & $1.342(10)$ & C6-N6 & $1.341(9)$ \\
\hline $\mathrm{N} 4-\mathrm{C} 3$ & $1.302(10)$ & $\mathrm{N} 6-\mathrm{C} 3$ & $1.308(9)$ \\
\hline $\mathrm{C} 3-\mathrm{N} 2$ & $1.327(10)$ & $\mathrm{C} 3-\mathrm{N} 2$ & $1.295(8)$ \\
\hline $\mathrm{N} 3-\mathrm{Pt}-\mathrm{N} 2$ & $83.2(3)$ & $\mathrm{N} 1-\mathrm{Pt}-\mathrm{N} 2$ & $84.5(3)$ \\
\hline $\mathrm{N} 3-\mathrm{Pt}-\mathrm{P} 1$ & $94.73(19)$ & $\mathrm{N} 1-\mathrm{Pt}-\mathrm{P} 1$ & $93.80(19)$ \\
\hline $\mathrm{N} 3-\mathrm{Pt}-\mathrm{P} 2$ & $172.38(18)$ & $\mathrm{N} 1-\mathrm{Pt}-\mathrm{P} 2$ & $172.7(2)$ \\
\hline $\mathrm{N} 2-\mathrm{Pt}-\mathrm{P} 1$ & $169.2(2)$ & $\mathrm{N} 2-\mathrm{Pt}-\mathrm{P} 1$ & $172.55(19)$ \\
\hline $\mathrm{N} 2-\mathrm{Pt}-\mathrm{P} 2$ & $90.0(2)$ & $\mathrm{N} 2-\mathrm{Pt}-\mathrm{P} 2$ & $88.23(18)$ \\
\hline $\mathrm{P} 1-\mathrm{Pt}-\mathrm{P} 2$ & $92.58(9)$ & $\mathrm{P} 1-\mathrm{Pt}-\mathrm{P} 2$ & $93.33(8)$ \\
\hline $\mathrm{N} 3-\mathrm{C} 4-\mathrm{N} 4$ & $127.5(9)$ & $\mathrm{N} 1-\mathrm{C} 6-\mathrm{N} 6$ & 127.2(8) \\
\hline $\mathrm{C} 4-\mathrm{N} 4-\mathrm{C} 3$ & $122.8(8)$ & $\mathrm{C} 6-\mathrm{N} 6-\mathrm{C} 3$ & $124.0(7)$ \\
\hline $\mathrm{N} 4-\mathrm{C} 3-\mathrm{N} 2$ & 126.7(8) & $\mathrm{N} 6-\mathrm{C} 3-\mathrm{N} 2$ & $126.5(8)$ \\
\hline
\end{tabular}

Moreover, the interconversion between the conformers is confirmed by the presence of pure dipolar correlations in the ${ }^{31} \mathrm{P}-{ }^{1} \mathrm{H}$ NMR HOESY spectrum shown in Figure 3, together with the expected heteronuclear ${ }^{31} \mathrm{P}-{ }^{1} \mathrm{H}$ NMR scalar correlations (Figure S3 in the Supporting Information).

It is interesting to note that the previously reported acetonitrile analogue showed identical NMR behavior. ${ }^{3}$

Crystal and Molecular Structures of 2 and 4. The X-ray structural determinations of $\mathbf{2}$ and $\mathbf{4}$ show that the insertion of a $\mathrm{PhCN}$ molecule into the cytosine $\mathrm{Pt}-\mathrm{N} 4$ and adenine $\mathrm{Pt}-\mathrm{N} 6$ bonds had occurred with the formation of a six-membered ring, as depicted in Figures 4 and 5, respectively. Selected bond distances and angles are collected in Table 3.

In the two adducts, the $\mathrm{Pt}$ is bound to the nucleobase $\mathrm{N}$ donor site, the inserted benzonitrile nitrogen N2, completing the square-planar coordination through $\mathrm{P}$ donors. The $\mathrm{Pt}-\mathrm{N}$ (nucleobase) bond lengths are 2.112(7) and 


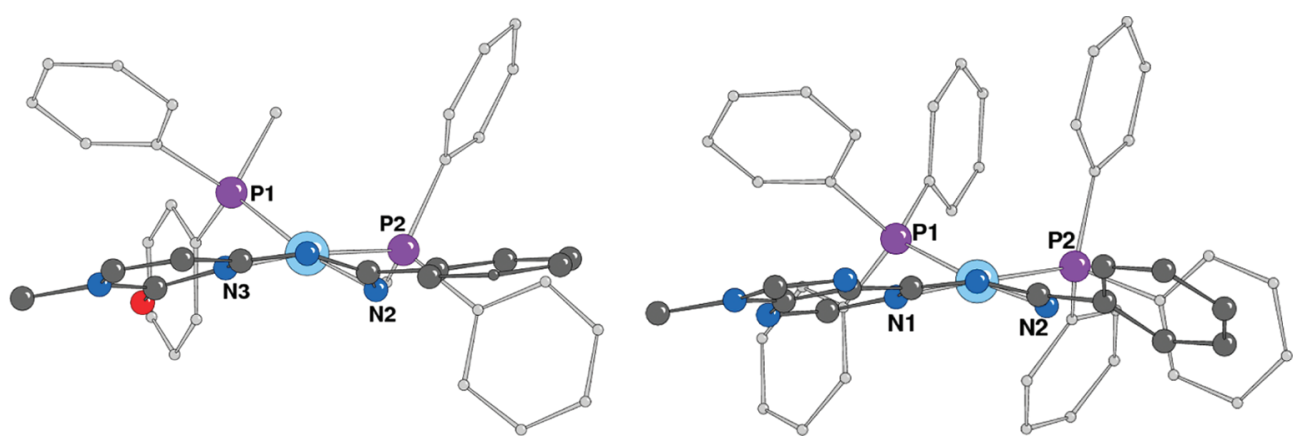

Figure 6. Side views of $\mathbf{2}$ (left) and $\mathbf{4}$ (right) showing the conformation of the nucleobase benzimidamide with respect to the coordination plane.

2.116(6) $\AA$ in $\mathbf{2}$ and 4, respectively, while $\mathrm{Pt}-\mathrm{N} 2$ bond lengths, of 2.043(6) and 2.010(6) $\AA$, are slightly shorter. The $\mathrm{Pt}-\mathrm{P}$ bond distances fall in the range from 2.271(2) to 2.313(2) ^. These values are comparable to those measured in the acetonitrile derivatives. ${ }^{3}$ The $\mathrm{N}_{2} \mathrm{P}_{2}$ donors show a slight tetrahedral distortion in $\mathbf{2}$, with deviations of $\pm 0.125 \AA$ from their mean plane, while milder deformations $( \pm 0.056 \AA)$ are measured in 4 . Figure 6 displays a side view of the complexes, showing the conformation assumed by the nucleobase benzimidamide moiety with respect to the coordination plane. The dihedral angle formed by the nucleobase ring with the $\mathrm{N}_{2} \mathrm{P}_{2}$ coordination plane is of $36.5(2)^{\circ}$ and $27.3(2)^{\circ}$ in $\mathbf{2}$ and $\mathbf{4}$, respectively. The phenyl from benzonitrile is almost coplanar with the cytosine ring in $\mathbf{2}$, while it is tilted with respect to the adenine in $\mathbf{4}$. Inside the six-membered-ring fragment, the geometrical parameters are comparable in the two cases and indicate an electron delocalization. The more apparent difference is observed for the $\mathrm{C} 3-\mathrm{N} 2$ bond distance, which is 1.327(10) and 1.295(8) $\AA$ in $\mathbf{2}$ and 4, respectively. Making allowance for the estimated standard deviations, the value measured in $\mathbf{2}$ is also longer than the distances measured in the crystal structures with acetonitrile, viz., 1.279(11) $-1.295(7) \AA^{3}{ }^{3}$

In complex 2, the short distance measured between the 1-MeCy oxygen atom with phosphorus P1 and with the ipso carbon $\mathrm{C} 14$ of the phosphine (2.88 and $2.92 \AA$, respectively) is an indication of a weak intramolecular bonding interaction, and it gives support to the observed behavior in solution (see the NMR results) for this species. The corresponding values in the acetonitrile derivative were found to be 3.08 and $3.00 \AA$, respectively. On the other hand, complex 4 shows an intramolecular stacking between the phenyl rings $\mathrm{C} 28$ and $\mathrm{C} 40$ of $\mathrm{PPh}_{3}$ [distance between centroids of 3.731(6) $\AA$; dihedral angle $\left.6.4(5)^{\circ}\right]$, while the stacking between the six-membered adenine ring and phenyl C16 appears marginal [3.924(6) $\AA$; $\left.37.5(5)^{\circ}\right]$. Finally, an edge-to-face $\mathrm{CH} \cdots \pi$ interaction is observed between the hydrogen atom $\mathrm{C} 11-\mathrm{H}$ and ring $\mathrm{C} 46$ $(\mathrm{H}-$ phenyl centroid distance $=2.87 \AA)$. This kind of stabilizing interaction, the so-called $\pi$-hydrogen bond, was sometimes observed in organometallic complexes ${ }^{15}$ and could support the observed stability of the benzonitrile with respect to the acetonitrile derivatives. In principle,

(15) (a) Ceccon, A.; Bisello, A.; Crociani, L.; Gambaro, A.; Ganis, P.; Manoli, F.; Santi, S.; Venzo, A. J. Organomet. Chem. 2000, 600, 94-111. (b) Bisello, A.; Ceccon, A.; Gambaro, A.; Ganis, P.; Manoli, F.; Santi, S.; Venzo, A. J. Organomet. Chem. 2000, 593-594, 315-324. (c) Ganis, P.; Ceccon, A.; Köhler; Manoli, F.; Santi, S.; Venzo, A. Inorg. Chem. Commun. 1998, 1, 15-18. this interaction (although not observed in the solid state likely for the packing requirement) is also feasible in complex 2 (distance between $\mathrm{C} 8-\mathrm{H}$ and centroid C33 ring $=3.06 \AA)$.

The difference Fourier maps allow one, in both structural determinations, to prudently fix the proton on the benzonitrile nitrogen N2 as determined through NMR.

Reaction of cis- $\left[\left(\mathrm{PPh}_{3}\right)_{2} \mathbf{P t N H}=\mathbf{C}(\mathbf{R})\{\text { 9-MeAd }(-2 \mathrm{H})\}\right]^{+}$ $(\mathrm{R}=\mathrm{Ph}, \mathrm{Me})$ and cis- $[(\mathrm{dppe}) \mathrm{PtNH}=\mathrm{C}(\mathrm{Ph})\{1-\mathrm{MeCy}-$ $(-\mathbf{2 H})\}]^{+}$with Hacac. In order to characterize the benzimidamide ligands, the reactivity of the new complexes toward Hacac has been investigated. This weakly acidic molecule $\left(\mathrm{p} K_{\mathrm{a}}=8.95\right)^{16}$ has well-established chelating properties in its deprotonated form $\left(\mathrm{acac}^{-}\right),{ }^{17}$ and it is expected to replace the anionic ligand in $\mathbf{1 - 5}$. In fact, complex 4 dissolves in pure Hacac in a few minutes at room temperature to give a pale-yellow solution. Its ${ }^{31} \mathrm{P}$ NMR spectrum exhibits two signals at $\delta 11.58$ and 9.09, flanked by ${ }^{195} \mathrm{Pt}$ satellites. The lower field signal, observed as an apparent singlet having a relative intensity of $60 \%$ with a rather large line width, is attributable to the unreacted complex 4. The sharp singlet at $\delta 9.09$ is due to the reaction product, namely, the complex cis-[( $\left.\left.\mathrm{PPh}_{3}\right)_{2} \mathrm{Pt}(\mathrm{acac})\right] \mathrm{NO}_{3}$, which contains the chelating acetylacetonate ligand. After 2 days at room temperature, this is the only detectable signal, indicating that the anionic ligand in $\mathbf{4}$ has been quantitatively replaced by $\mathrm{acac}^{-}$. The compound cis-[( $\left.\mathrm{PPh}_{3}\right)_{2} \mathrm{Pt}($ acac $\left.)\right] \mathrm{NO}_{3}$, previously characterized as a $\mathrm{BPh}_{4}$ salt, ${ }^{18}$ can be quantitatively prepared by dissolving the hydroxo complex cis- $\left[\left(\mathrm{PPh}_{3}\right)_{2} \mathrm{Pt}(\mu-\mathrm{OH})\right]_{2}\left(\mathrm{NO}_{3}\right)_{2}$ in Hacac, where it reacts immediately (see the Experimental Section). The complete characterization of the organic moiety $\mathrm{NH}=\mathrm{C}(\mathrm{Ph})\{9-\mathrm{MeAd}(-\mathrm{H})\}$ resulting from the ligand exchange will be reported elsewhere. ${ }^{19}$ It can be anticipated that ${ }^{1} \mathrm{H}$ NMR analysis of the solid-state residue and of the liquid components of the reaction mixture, separated under vacuum and dissolved in DMSO- $d_{6}$ and $\mathrm{CDCl}_{3}$, respectively, rules out the presence of free 9-MeAd and benzonitrile. Similarly, the acetonitrile analogue of $\mathbf{4}$, cis-[( $\left.\mathrm{PPh}_{3}\right)_{2} \mathrm{PtNH}=\mathrm{C}(\mathrm{Me})\{9-\mathrm{MeAd}-$ $(-2 \mathrm{H})\}] \mathrm{NO}_{3},{ }^{3}$ reacts easily in pure Hacac to give quantitatively cis-[( $\left.\left.\mathrm{PPh}_{3}\right)_{2} \mathrm{Pt}(\mathrm{acac})\right] \mathrm{NO}_{3}$, as shown by the

(16) Leipoldt, J. G.; Grobler, E. C. Transition Met. Chem. 1986, 11, 110112.

(17) De Pascali, S. A.; Papadia, P.; Ciccarese, A.; Pacifico, C.; Fanizzi, F. P. Eur. J. Inorg. Chem. 2005, 788-796.

(18) Ito, T.; Kiriyama, T.; Yamamoto, A. Bull. Chem. Soc. Jpn. 1976, 49, 3250-3256.

(19) Montagner, D.; Zangrando, E.; Longato, B. Manuscript in preparation. 
${ }^{31} \mathrm{P}$ NMR spectrum recorded immediately after dissolution of the complex.

A different behavior was observed for complex 3 . Even though it dissolves easily in Hacac, protonation of the coordinated ligand $\mathrm{NH}=\mathrm{C}(\mathrm{Ph})\{1-\mathrm{MeCy}(-2 \mathrm{H})\}$ occurs only to a minor extent. In fact, the ${ }^{31} \mathrm{P}$ NMR spectrum of the resulting solution shows $A B$ multiplets of 3 [at $\delta 40.7\left({ }^{1} J_{\mathrm{PPt}}=3347\right)$ and $36.35\left({ }^{1} J_{\mathrm{PPt}}=\right.$ 3386)] and a singlet at $\delta 31.41$ flanked by ${ }^{195} \mathrm{Pt}$ satellites $\left({ }^{1} J_{\mathrm{PPt}}=3879 \mathrm{~Hz}\right)$, having a relative intensity ratio of $4: 1$. This latter signal is clearly attributable to cis-[(dppe)Pt(acac) $] \mathrm{NO}_{3}$ (see the Experimental Section). The spectrum does not change after several days, indicating that the reaction mixture is at equilibrium. If Hacac is replaced by the more acidic hexafluoroacetylacet one $\left(\mathrm{p} K_{\mathrm{a}}=4.35\right),{ }^{16}$ the equilibrium appears strongly shifted toward protonation of 3 . In this case, the relative abundance of 3 and cis-[(dppe) $\mathrm{Pt}(\mathrm{hfacac}) \mathrm{NO}_{3}$ was $1: 1.5$. The latter species, observed in the ${ }^{31} \mathrm{P}$ NMR spectrum as a singlet at $\delta 37.12$ with ${ }^{1} J_{\mathrm{PPt}}=3860 \mathrm{~Hz}$, is quantitatively formed when cis-[(dppe) $\mathrm{Pt}(\mu-\mathrm{OH})]_{2}$ $\left(\mathrm{NO}_{3}\right)_{2}$ is dissolved in hfHacac.

\section{Conclusions}

The first examples of azametallacycles resulting on the formal insertion of benzonitrile into $\mathrm{Pt}^{\mathrm{II}}-\mathrm{N}$ bonds of nucleobase complexes are described. The compounds $c i s-\left[\mathrm{L}_{2}-\right.$ $\mathrm{PtNH}=\mathrm{C}(\mathrm{Ph})\{9-\mathrm{MeAd}(-2 \mathrm{H})\}]^{+}$and $c i s-\left[\mathrm{L}_{2} \mathrm{PtNH}=\mathrm{C}(\mathrm{Ph})-\right.$ $\{1-\mathrm{MeCy}(-2 \mathrm{H})\}]^{+}$have been obtained when the neutral ligands $\mathrm{L}$ are $\mathrm{PPh}_{3}, \mathrm{PMePh}_{2}$, and dppe but not with the more basic phosphine $\mathrm{PMe}_{2} \mathrm{Ph}$.

Unlike the acetonitrile analogues, which release $\mathrm{CH}_{3} \mathrm{CN}$ in DMSO or chlorinated solvents, ${ }^{3}$ the benzonitrile derivatives here reported are indefinitely stable in solution. The higher thermodynamic stability of these substituted benzamidine complexes could be ascribed (i) to a more extended $\pi$-electron delocalization in the organic ligand due to the presence of the phenyl group and (ii) to an edge-to-face $\mathrm{CH} \cdots \pi$ interaction between a $P h C N$ phenyl hydrogen with one $\mathrm{PPh}_{3}$ phenyl ring, clearly evidenced in the X-ray structure of 4 .

The anionic ligands in $c i s-\left[\left(\mathrm{PPh}_{3}\right)_{2} \mathrm{PtNH}=\mathrm{C}(\mathrm{R})\{9-\mathrm{MeAd}-\right.$ $(-2 \mathrm{H})\}] \mathrm{NO}_{3}(\mathrm{R}=\mathrm{Me}, \mathrm{Ph})$ can be quantitatively protonated by Hacac, leading to formation of the free amidines $\mathrm{NH}=\mathrm{C}$ (R) $\{9-\operatorname{MeAd}(-\mathrm{H})\}$ and the acetylacetonate complex cis-[$\left(\mathrm{PPh}_{3}\right)_{2} \mathrm{Pt}(\mathrm{acac}) \mathrm{NO}_{3}$. The incomplete protonation of the anionic ligand in $\mathbf{3}$ by Hacac or hfHacac is likely due to electronic effects related to the presence of dppe, which is more basic in comparison with the $\mathrm{PPh}_{3}$ ligand.

Supporting Information Available: Crystallographic data for the structures reported in this paper. This material is available free of charge via the Internet at http://pubs.acs.org. 